\title{
ENHANCING THE SPEAKING PERFORMANCE OF EFL COLLEGE STUDENTS THROUGH VIDEO PROJECTS
}

\author{
Yuli Astuti Hasanah ${ }^{1}$, Satria Adi Pradana ${ }^{2}$ \\ English Department at IAIN Kediri ${ }^{1}$, UIN Raden Intan Lampung ${ }^{2}$ \\ yulihasan@gmail.com
}

\begin{abstract}
The study described how video projects were used to enhance the speaking performance of EFL college students in IAIN Kediri, Indonesia. The researcher found that students faced technical and personal problems appeared in the speaking class. A classroom action research was applied to the study to solve the problems. Then, the data was analyzed descriptively. The result of the study identified that students emerged confidence, fluency, good collaboration and excitement in the speaking class. The study resulted that obstacles of speaking English can be solved alternatively through the used of song videos as the project by practicing the aspects of the language in song lyrics and producing videos which then were spread out through YouTube website in order to appreciate their work and creativity as well as to share it as useful sources of teaching media and also entertainment.
\end{abstract}

Key words: classroom action research, speaking performance, video projects 


\section{A. INTRODUCTION}

Speaking is always becoming a serious problem for some people when studying English because not many people get used to speak in public even in their own mother language. Therefore, speaking has been the researcher's concerns as teaching English for college students should properly be able to demonstrate the students' speaking ability since they are now advanced learners. Moreover, many college programs require students to demonstrate learned skills ${ }^{1}$. Based on the study conducted by Tuan and Mai, it was found that there were factors that affect students' speaking performance. Most of the students thought that their speaking performance was affected by topical knowledge, listening ability, confidence, feedback during speaking activities and the pressure to perform well ${ }^{2}$.

Furthermore, based on the previous study in the speaking class, the researcher similarly found several obstacles at the first time of asking students to speak English which was not familiar to be used in their life. Therefore, the researcher sums up that the problems are technical and personal. The technical problems are about the techniques of teaching used in the class as well as the regular practices of the language. For the techniques of teaching, there are so many techniques can be used from many references and technologies. However, for the regular practices of the language, it depends on the users themselves; how often they practice and experience the language to keep it in mind. Secondly is the personal problems. The most common and noticeable personal problems are nervousness, confidence, shyness, and fear. The nervousness is because they rarely perform in front of the public. The confidence is because they lack the speaking ability such as grammar, vocabulary, pronunciation, fluency, accents, and so on. The shyness comes when they are not truly confident with their own potentials which they actually can speak and have the knowledge about it but they are reluctant to speak up. And, the last is fear as students are very afraid of making mistakes which then being laughed by their friends and causing corrections or

\footnotetext{
${ }^{1}$ McLellan, Sylvia. November 2008. When Students Teach: Performance Based Assessment. Transformative Dialogues: Teaching \& Learning Journal Volume 2, Issue 2.

${ }^{2}$ Tuan, Nguyen Hoang \& Mai, Tran Ngoc. 2015. Factors Affecting Students' Speaking Performance at Le Thanh Hien High School. Asian Journal of Educational Research Vol. 3, No. 2.
} 
comments by the lecturer because of their less speaking skills. Thus, by considering all the problems revealed, the research question is formulated as: How can video projects enhance the speaking performance of EFL college students?. The objective of this study outlines to find out the implementation of video projects to improve the students' speaking performance in the speaking class. It shows how are the teaching procedures, the students' feedback and creations on video projects.

\section{B. LITERATURE REVIEW}

Siahaan Stated that Speaking is a productive language skill. It means Speaking producing language. Therefore, in speaking class the students need to practice the language by speaking performance. That performances are ways to demonstrate the application of theory to practice ${ }^{1}$. Through speaking performance, the students can implement the knowledge from theory to be practiced in real. To know the students' performances, the proper assessment should have met the skill to be measured. Performance based assessment is considered as one of the best assessment techniques in measuring the development of $21^{\text {st }}$ century students' skills than traditional assessment ${ }^{3}$. By having performance based assessment in speaking, the students are equipped to do the task which is measured based on their skills. In addition, the speaking performance can be measured through fluency, accuracy, syntactic complexity, and lexical complexity and what speaking performance measures can be used as indicators of speaking ability. ${ }^{4}$

As in the global era and the technology development, it is considerable to integrate multimedia technologies in the language classroom. Therefore, this study will utilize the use of technology to assess students' performance by using song videos.

\footnotetext{
${ }^{3}$ Rosaroso, Rufina C. \& Rosaroso, Nelson A. November 2015. Performance-based Assessment in Selected Higher Education Institutions in Cebu City, Phillipines. Asia Pacific Journal of Multidisciplinary Research, Vol. 3, No. 4, Part IV.

${ }^{4}$ Koizumi, R. 2005. Speaking performance measures of fluency, accuracy, syntactic complexity, and lexical complexity [スピーキングパフォーマンスの流暢さ・正確 さ・統語的複雑さ・語彙的複 雑さの指標]. JABAET (Japan-Britain Association for English Teaching) Journal, 9, 5-33.
} 
Through the use of video materials, English as a second language (ESL) students are afforded the opportunity to observe and participate in a more active learning experience, while maximizing the use of several cognitive skills ${ }^{5}$. Video is considered as a visual technology which aid the viewers through visual and audio senses. It is in lined with Maria who stated that visual aids also clarify the meaning of words and messages, help in memorizing new vocabulary, and in gaining students attention ${ }^{6}$. It means that by having video the viewers are helped visually not only through words written but also the gestures which then can improve vocabulary and attract the viewers' attention visually and audibly. In addition, in this study the researcher combines the use of video together with songs which then called its technique as song videos. According to Shen, songs provide beneficial use in speaking namely: teaching natural pronunciation efficiently, demanding familiarity with a number of phonological rules (for instance, liaison, loss of explosion, assimilation, voicing, deletion, insertion and so on are the most common phenomena that occur nearly in every English song), getting familiar with and internalize them through repetition and imitation, paying more deliberate attention to pronunciation, phonological rules, stress and intonation, and thus pronouncing more correctly and speaking English more fluently ${ }^{7}$. The resources of song videos can be accessed through YouTube website. As suggested by Almurashi, YouTube could be a good material to incorporate English lessons and it can help with understanding the lesson as well. He also adds that YouTube website can be an effective method in dealing with students' difficulties and barriers in understanding English ${ }^{8}$. Therefore, by considering the beneficial use of song videos in improving students' speaking performances, the researcher was interested to apply this technique to her English speaking class.

\footnotetext{
${ }^{5}$ Williams, R.T., and Lutes, Peter. 2013. Using video in the ESL classroom. 高松大学紀要 Volume 48, No 1.

${ }^{6}$ Maria, Ramírez García. 2012. Usage of Multimedia Visual Aids in the English Language Classroom: A Case Study at Margarita Salas Secondary School (Majadahonda).

${ }^{7}$ Shen, Chunxuan. March 2009. Using English Songs: An Enjoyable and Effective Approach to ELT. English Language Teaching (ELT) Journal, Vol 2 No. 1.

${ }^{8}$ Almurashi, Wael Abdulrahman. April 2016. The Effective Use of YouTube Videos for Teaching English Language in Classrooms as Supplementary Material at Taibah University in Alula. International Journal of English Language and Linguistics Research Vol.4, No.3, pp.32-47.
} 


\section{METHODOLOGY}

The method used in this study was a classroom action research. It started by recognizing problems appeared to the researcher's speaking class. Considering some references of alternative strategies, the researcher applied a video project as the solution. The subject of the study was the second semester students of IAIN Kediri in the academic year of $2016 / 2017$. Below are the procedures of the implementation which are divided into several subsections: Planning the course, procedures of classroom activities, and reflection.

\section{RESULT}

\section{Planning the course}

In the planning, the researcher arranged the course outline which contains the schedule of the study, the objectives, timelines, assessments, group working, presentations, discussions and a final project. The study combined the lecturing on the course materials done in the classroom and the process of creating video project done beyond the classroom. The course required a series of process namely: introducing song lyrics, analyzing song lyrics through group discussion and presentation, performing song videos for final project, and publishing the project through YouTube website.

\section{Procedures of classroom activities}

In the first meeting, the students were delivered the materials of teaching: a western song lyrics and its video through the laptop, LCD and projector. Students were given tasks to listen the video of the song and filled in ten blanks of lyrics for three times. Then, students checked the correct answers to know how well their listening ability guided by the lecturer. After that, students were asked to work in a group of four or five discussing the content of the song including the meanings, the structures or grammar used, to whom the song is delivered and the messages. Having finished the work, each group presented the result of their work and discussed the issues in front of the class. The audiences were permitted to ask questions or gave comments and suggestions. As reflections, the students were asked to practice the song to train 
their pronunciation and fluency. Finally, students sang the song together while also playing the video.

For the second meeting, students were given a task. They were asked to find their own favorite western song and practiced it at home in a group of three to five. They had to discuss in their group to decide their choice. They were asked to analyze the lyrics in the term of the meanings, the structures or grammar used, to whom the song was delivered and the messages. The purposes of analyzing of the lyrics were to know the content of the song, to whom the song actually is delivered, and its messages, thus, while performing or singing the song they could feel and express the song naturally. Then, students did a presentation and discussion the song chosen. Students were free to discuss, give comments or suggestion each other to improve their knowledge and experiences.

In the third meeting, students performed to sing along the song within their group. The students were assessed using the speaking scoring rubrics measured pronunciation, fluency, confidence, and collaboration.

In the fouth and fifth meeting was done for the final project in which the students were asked to practice the song chosen and made it as the video project beyond the classroom. For this task, the lecturer gave independence to the students to be as creative as possible in making the video in order to maximize the students' interest and creativity. They were encouraged to develop their creativity based on their interest unless there were no contradictory or provocative issues. In addition, the students were given opportunity to ask the lecturer any difficulties and directions during the video-making processing. For the video project, the students were given two weeks for finishing it. The process of recording the videos were done beyond the classroom.

\section{Reflection}

The reflection of the study was done through questionnaires and interviews. The students were interviewed and asked to fill in the questionnaire by giving check to the column to evaluate the teaching and learning process. The questionnaires were as follows: 


\begin{tabular}{|c|c|c|c|c|c|c|c|}
\hline No & Questions & $\mathbf{1}$ & 2 & 3 & 4 & 5 & Comments \\
\hline 1 & $\begin{array}{l}\text { Do you think your English } \\
\text { pronunciation is getting better by using } \\
\text { video projects? }\end{array}$ & & & & & & \\
\hline 2 & $\begin{array}{l}\text { Do you think your English fluency is } \\
\text { getting better by using video projects? }\end{array}$ & & & & & & \\
\hline 3 & $\begin{array}{l}\text { Do you think your confidence is getting } \\
\text { better by using video projects? }\end{array}$ & & & & & & \\
\hline 4 & $\begin{array}{l}\text { Do you think you can collaborate well } \\
\text { with others by using video projects? }\end{array}$ & & & & & & \\
\hline 5 & $\begin{array}{l}\text { Do you like / happy using video } \\
\text { projects used in the teaching learning } \\
\text { process? }\end{array}$ & & & & & & \\
\hline 6 & $\begin{array}{l}\text { What will you suggest about the } \\
\text { strategy of using video projects for } \\
\text { your speaking class? }\end{array}$ & & & & & & \\
\hline
\end{tabular}

Scale:

1. Very poor / very low

2. Poor / low

3. Fair / enough

4. Good / high

5. Very good / very high

The questionnaires were distributed to all the students to be filled and submitted to the lecturer. The results showed that in the first category, 95\% students responded that their English pronunciation were good/high by using video projects since most of time they practiced the songs, while the rest said fair/enough. For the second category on English fluency, 85\% of students responded good/high, 5\% students said very good/very high, and the rest was fair/enough as the fluency was limited on the song that they have been practiced. The third category on confidence, $100 \%$ students responded to have very good/very high confidence while performing 
song videos. The forth category on collaboration, 95\% students responded that they could collaborate well since the technique attributed the students to work within group through discussion and final project, while, 5\% students responded fair/enough in collaboration since for some times within the members of their group, they had difficulty in managing the best schedule for making videos beyond the classroom. At last, in the category on the students' suggestion about the strategy of using video projects for their speaking class, $70 \%$ students suggested good/high and 30\% students suggested very good/very high.

The interviews were done to tentative students to know their opinions about the technique. The students mostly responded that the technique of teaching using video projects was very good and interactive. First, this technique brought the students of speaking English into the real practice and aroused the students' interest of studying English. One of students said," I like this class because the lesson is not only about theory but also practice to real". "We do practice English by making video into real", she added. Another also said," The previous English lecturer was boring and the class makes us sleepy because we study grammar and do paper-pencil test". Other students also responded, "See you for the next class Miss, I like your class because we practice the English into real. Although, our English is not fluent but you are so patience to teach us". Second, creating video projects through songs stimulated the students' creativity. Some students responded, "By having task of making video, it forced us to be as creative as possible and we feel so challenge". Other students said, "Making video songs makes us think more what have to do with the project and try to give the best for the best final result". Finally, this technique creates good ambience of speaking class. Most of students said, "I like the atmosphere of this class, we are free to speak English although our English not really good". Others also responded, "The class does use English into real practice and we practice it in relaxed and comfortable situation so we are not afraid to speak English". In addition, for final task of song videos can be reached through YouTube website through the researcher's channel: Yulia Hasanah at https://www.youtube.com/channel/UCOiqfjBHxBuCuJqQFRB67Fg 


\section{E. CONCLUSION}

To sum up, the researcher concludes that technique of using video projects in the speaking class has reached very good satisfaction. The technique arouses the students' excitement in the speaking class, creates students' creativity and makes comfortable ambience of English speaking class. The students become active to explore the potential inside about their English skills not only speaking but also listening and reading. Therefore, it is highly suggested for lecturers, teachers and educators to apply this technique in the teaching and learning process in order to solve the same problem as well as to enrich the variation of good techniques during the English class. For the further researcher, this technique possibly can be combined to other materials and skills related to the study. 


\section{F. REFERENCES}

Almurashi, W. A. (2016). The Effective Use of YouTube Videos for Teaching English Language in Classrooms as Supplementary Material at Taibah University in Alula. International Journal of English Language and Linguistics Research, 4 (3), 32-47.

Koizumi, R. (2005). Speaking Performance Measures of Fluency, Accuracy, Syntactic Complexity, and Lexical Complexity [スピーキングパフォーマンスの流暢 さ・正確さ・統語的複雑さ・語彙的複 雑さの指標]. JABAET (JapanBritain Association for English Teaching) Journal, 9, 5-33.

Maria, R. G. (2012). Usage of Multimedia Visual Aids in the English Language Classroom: A Case Study at Margarita Salas Secondary School (Majadahonda).

McLellan, S. (2008). When Students Teach: Performance Based Assessment. Transformative Dialogues: Teaching \& Learning Journal, 2 (2), November 2008.

Rosaroso, R. C. \& Rosaroso, N. A. (2015). Performance-based Assessment in Selected Higher Education Institutions in Cebu City, Phillipines. Asia Pacific Journal of Multidisciplinary Research, 3 (4), Part IV.

Shen, C. (2009). Using English Songs: An Enjoyable and Effective Approach to ELT. English Language Teaching (ELT) Journal, 2 (1).

Tuan, N. H. \& Mai, T. N. (2015). Factors Affecting Students' Speaking Performance at Le Thanh Hien High School. Asian Journal of Educational Research, 3 (2).

Williams, R.T., and Lutes, P. (2013). Using video in the ESL classroom. 高松大学紀 要, 48 (1). 